\title{
UPDATE ON THE DISTRIBUTION OF BUFFALOGRASS IN SOUTHWESTERN MANITOBA
}

ELIZABETH REIMER, CARY HAMEL and MARILENA KOWALCHUK Manitoba Conservation Data Centre, Box 24, 200 Saulteaux Crescent, Winnipeg, MB R3J $3 \mathrm{~W} 3$

\section{Introduction}

In Manitoba's Souris River Valley, Buffalograss (Buchloë dactyloides) stolons creep over and around the stones of a longabandoned tipi ring. The sight draws the imagination back to a time when large herds of American Bison migrated through the valley, feeding on the abundant grasses.
Buffalograss is uniquely adapted to coexist with bison; the unusual bur-like seed structures stick to their long shaggy fur, making bison unwitting participants in seed dispersal, and grazing itself is beneficial to many grasses, including Buffalograss. Some speculate that Buffalograss could not survive at its northern limit of distribution in

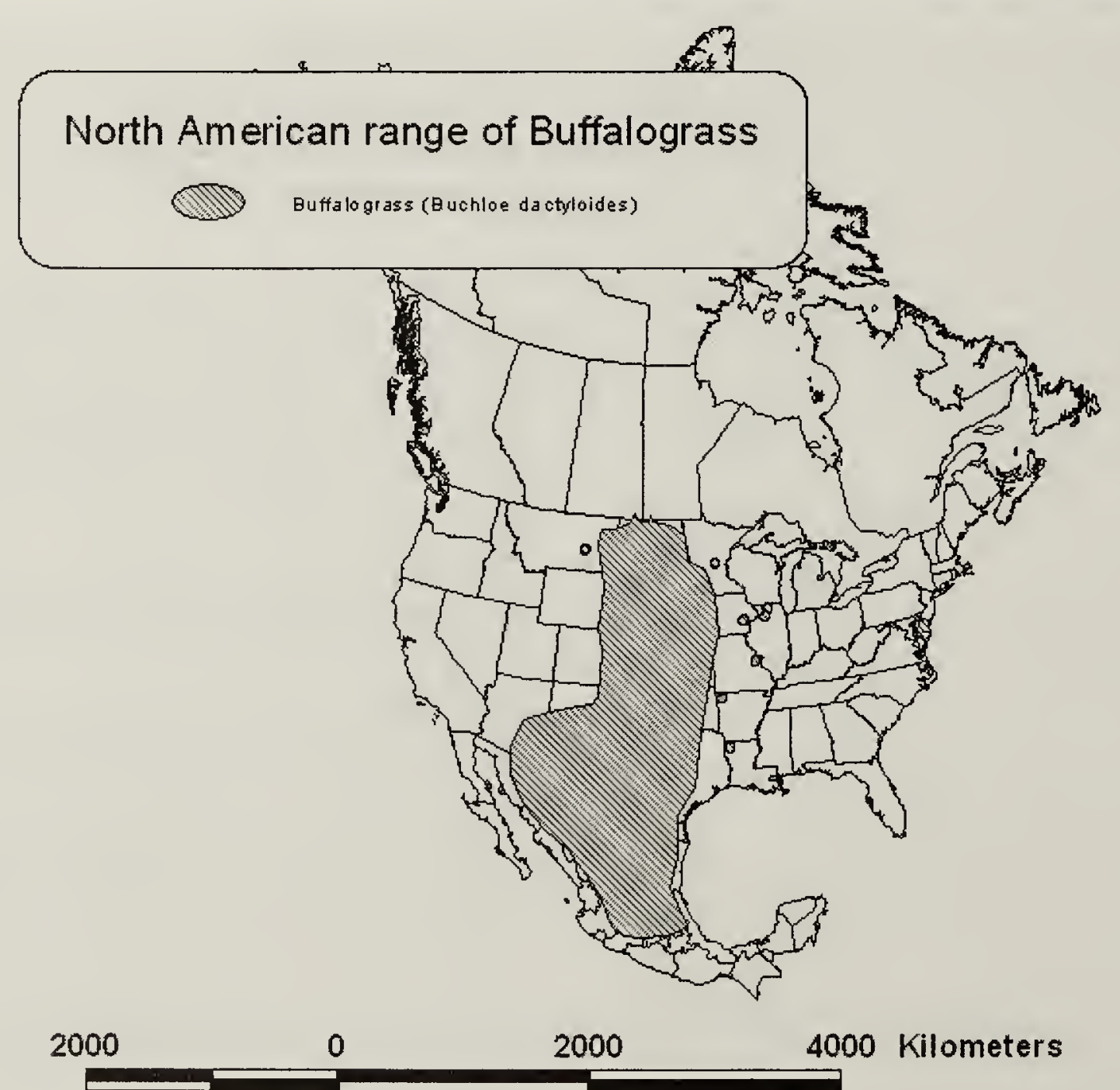

Figure 1. Range of Buffalograss (Buchloë dactyloides) in North America, from Harms 1997. 
Saskatchewan and Manitoba (Figure 1) without grazers to trim the taller plants that block out the sun for diminutive species like Buffalograss. ${ }^{4}$ Though bison no longer dominate the landscape, the cattle and horses that graze in the Souris River Valley have now taken on the role of maintaining Canadian populations of this plant.

Buffalograss is usually dioecious, that is with male and female flowers occurring on separate plants. Both sexes are occasionally found on the same clone in more southerly parts of the species' range. ${ }^{4}$ Several male spikes occur atop slender culms that reach up to $12 \mathrm{~cm}$ tall. The shorter, female flowering stems rarely grow taller than $5 \mathrm{~cm}$, and the spikes are concealed within the expanded sheaths of the upper leaves. ${ }^{1}$ The hardened glumes of the female spikelets form a burlike cluster (Figure 2) that detaches from the plant intact. Each cluster typically contains three to five seeds, and has the potential to produce some male and some female plants. ${ }^{4}$ The plant also reproduces asexually via stolons that spread on the surface, producing clones that can grow to $3 \mathrm{~m}$ or more in diameter. ${ }^{4}$ Buffalograss forms a dense sod in areas where clones crowd together. The spreading nature of Buffalograss helps to anchor soil, and it has been planted in roadside cuts to reduce soil erosion. ${ }^{7}$ It can also be used as a low-maintenance lawn grass. It is highly tolerant of drought, and valuable as winter forage for its high nutrient retention. In the American Midwest, Buffalograss sod was used to build houses in the early days of European settlement. ${ }^{4}$

Some farmers in the Coulter area call Buffalograss "prairie wool", although in other parts of the Prairie Provinces this term may refer to Rough fescue (Festuca hallii). The curled leaves that likely inspired the local moniker also lend Buffalograss, especially the male clones, a superficial resemblance to Blue Grama (Bouteloua gracilis). ${ }^{1}$ Blue Grama lacks stolons and possesses scaly rhizomes, and is generally taller than Buffalograss. ${ }^{4}$

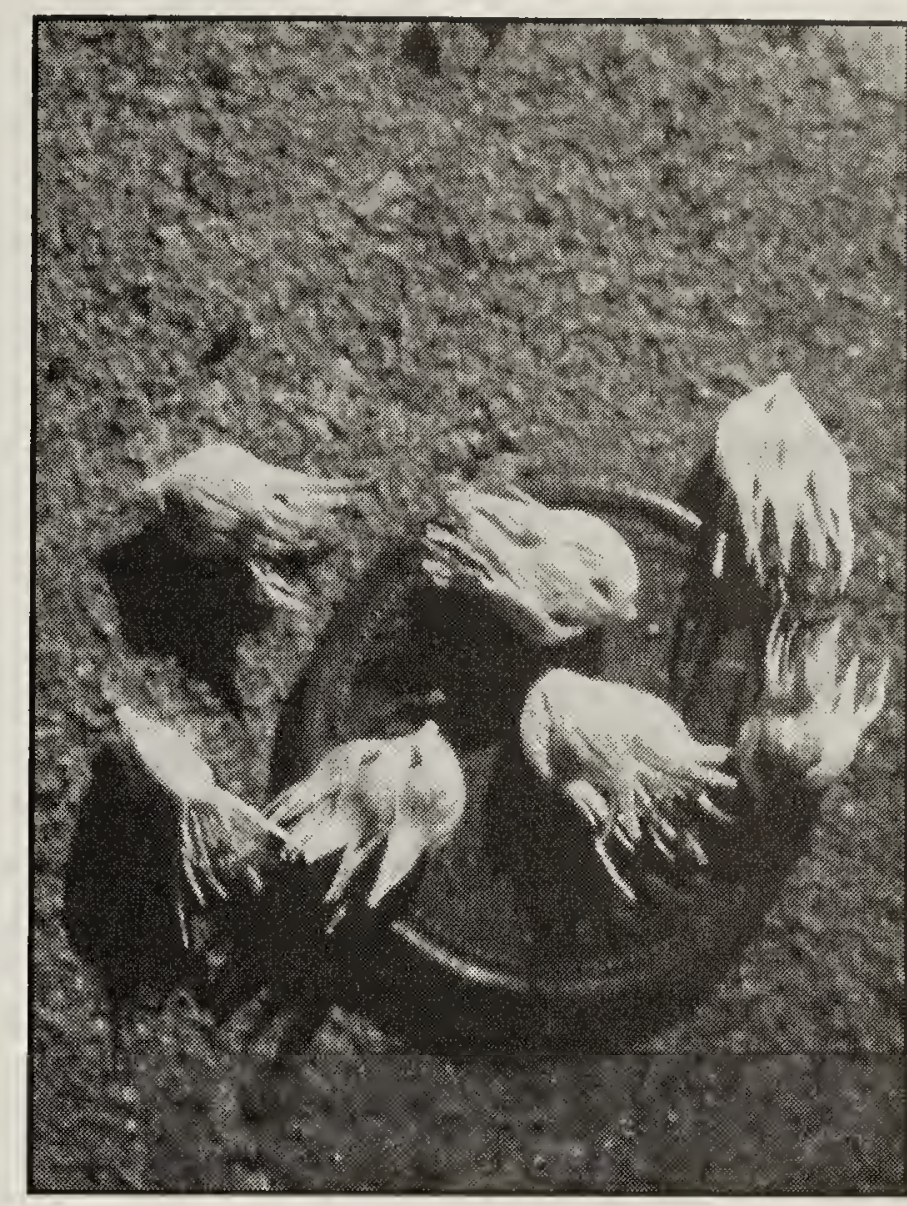

Figure 2. Bur-like clusters of buffalograss seed shown on a penny for scale.

\section{Status}

Buffalograss, listed as Vulnerable by the Committee on the Status of Endangered Wildlife in Canada (COSEWIC) in 1998, was uplisted to Threatened in 2001 based on a re-assessment using new, quantitative criteria. A species is ranked Threatened in the absence of demonstrated continuing decline if its area of occupancy is less than $20 \mathrm{~km}^{2}$, or if it occurs at fewer than five locations, as Buffalograss does. (A species with area of occupancy less than $500 \mathrm{~km}^{2}$, and extent of occurrence less than $5000 \mathrm{~km}^{2}$ is considered Endangered when continuing decline is observed or inferred.) In Manitoba, Buffalograss was not found within any protected areas, and all occurrences were found on privately owned land. The rarity of Buffalograss in Canada may reflect poor growing conditions at the northern edge of its range, or the species may be rare because of the widespread cultivation of native prairie in the early $20^{\text {th }}$ century. Buffalograss may have existed elsewhere before the advent of farming in Canada, in areas that are now cultivated. 
Although Buffalograss is rare at the periphery of its range in Canada and Minnesota, elsewhere it is an important component of the mixed-grass prairie and forms the dominant cover in parts of the west central Great Plains. ${ }^{4}$ NatureServe considers this species secure globally. ${ }^{6}$

The rarity of Buffalograss in Manitoba made it a priority for examination by Manitoba's Endangered Species Advisory Committee. This survey of native prairie in the Souris River Valley in southwestern Manitoba was conducted to collect current and complete information on the distribution and habitat preferences of Buffalograss. The survey was a partnership between the Manitoba Conservation Data Centre (CDC) and the Critical Wildlife Habitat Program's
Mixed Grass Prairie Inventory project, which was initiated in 1996 to identify the extent and quality of remaining mixed-grass prairie in Manitoba. Two other species considered rare (Baird's Sparrow, listed as Endangered by Manitoba's Endangered Species Act, and Sprague's Pipit, designated as Threatened by COSEWIC) were observed as part of the survey.

\section{Methods}

Site description

The Souris River enters Manitoba from North Dakota, and runs almost straight north to Melita before it curves eastward towards the town of Souris (Figure 3). The Souris and Blind rivers have deposited clay on the treeless floodplain south of Melita, and this is where Buffalograss grows (Figure 4).

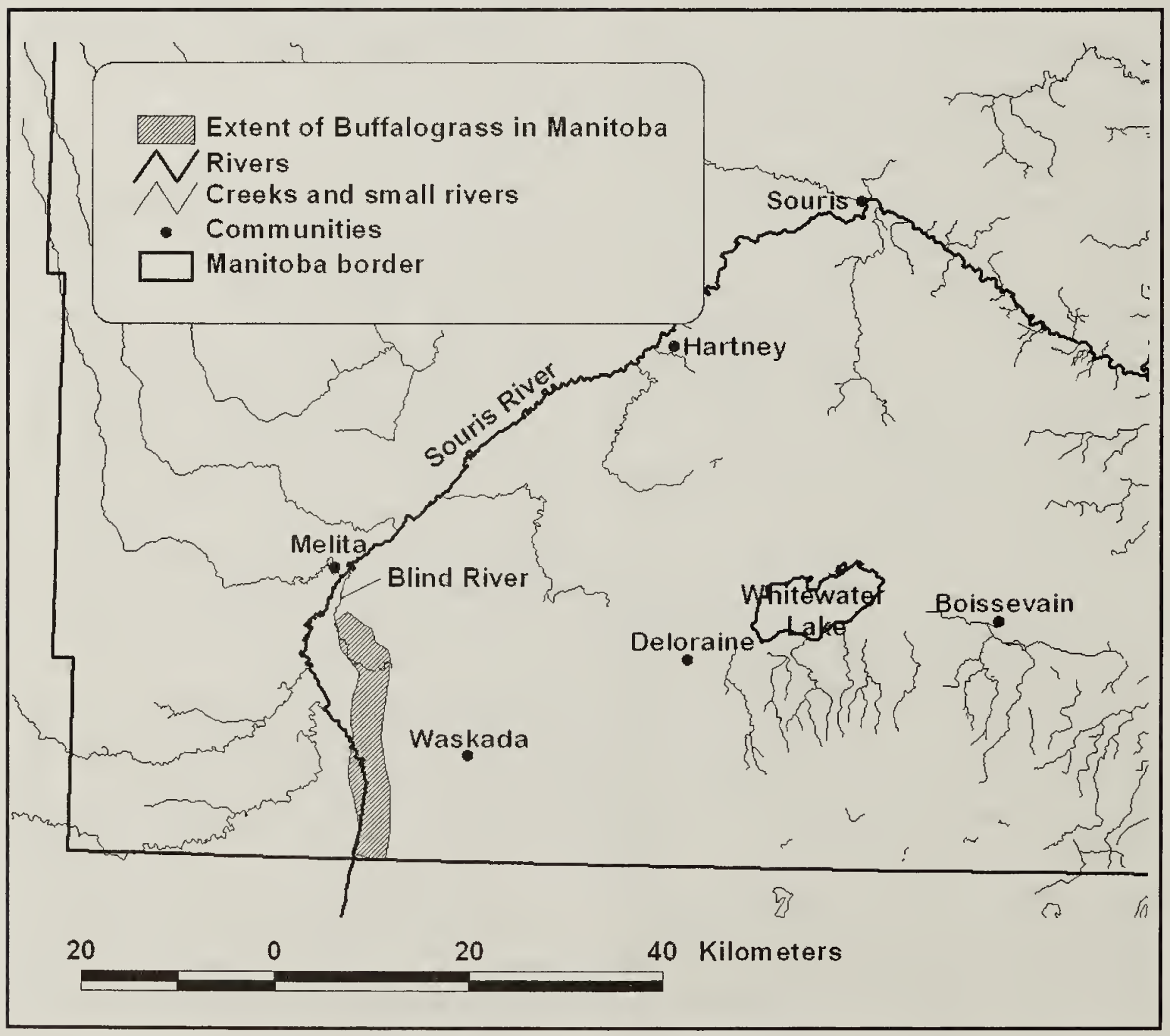

Figure 3. The extent of Buffalograss in Manitoba. The species occurs discontinuously within the shaded area. 
Alkaline flats are scattered throughout the valley bottom, often evident from the white crust on top of the soil. These areas are dominated by Inland Salt Grass (Distichlis stricta), and Buffalograss does not grow where alkaline deposits occur. From the Souris River, the elevation rises in a series of terraces and slopes carved by coulees and blanketed with grasses and wildflowers. Above the valley, most of the land is cultivated and sown to annual crops.

\section{Survey Methods}

Potential native prairie sites were identified using forest resource inventory maps, Landsat TM satellite imagery, and digital aerial photos. Prior to the survey, landowners were contacted by mail or telephone to request permission to access their property. The survey was conducted on foot between June 5 and July 29, 2002. On each quarter section surveyed, CDC staff recorded the extent of each patch of Buffalograss on an aerial photo. The data were digitized based on ortho photos (Linnet Geomatics) and entered into the CDC database using the Biotics 3.1 Geographic Information System application. Survey results were provided to all landowners who expressed an interest, as was a list of vascular plants observed on their property and information on Buffalograss, Sprague's pipit and the Manitoba Habitat Heritage Corporation's (MHHC) conservation agreement program.

\section{Results}

All Buffalograss occurrences in Manitoba were contained within an area approximately $61 \mathrm{~km}^{2}$ (Figure 3). It was observed on 42 quarter sections, all within the Rural Municipality of Arthur. Although Buffalograss habitat occurred along the Souris River and Blind River valleys in a band roughly $2 \mathrm{~km}$ wide and $25 \mathrm{~km}$ long, the distribution of Buffalograss within this area was not continuous; Buffalograss covered only $2.7 \mathrm{~km}^{2}$. Buffalograss was most abundant in lower slope positions. Within the area occupied, it represented between
20 and 80 percent of the ground cover. Characteristic species associated with Buffalograss in the Souris River Valley included Western Wheatgrass (Agropyron smithii), Kentucky Bluegrass (Poa pratensis), Needle and Thread (Stipa comata), Curlycup Gumweed (Grindelia squarrosa), Prairie Sagewort (Artemisia frigida), Foxtail Barley (Hordeum jubatum), Blue Grama (Bouteloua gracilis), Inland Salt Grass (Distichlis stricta), and Alkali Cordgrass (Spartina gracilis).

\section{Discussion}

In 1997, Harms estimated the population of Buffalograss in Manitoba to be 4,858 clones by extrapolation based on the total areal extent of Buffalograss and the average area that a single clone covered. ${ }^{4}$ Using the same method of extrapolation that Harms used, the population in Manitoba was estimated to be between 220,000 and 860,000 clones. It is unlikely that Buffalograss has expanded its range since research was conducted for the COSEWIC report in 1997; therefore, this apparent increase likely reflects the fact that this survey covered a larger territory.

The area of occupancy, $2.7 \mathrm{~km}^{2}$, remains well below the threshold indicated by COSEWIC's quantitative criteria for threatened species. This additional information on the distribution of Buffalograss does not likely warrant a change in its status. Further surveys of mixed-grass prairie in Manitoba are unlikely to result in additional occurrences, because the preferred habitat and soil type are restricted to the study area. The Mixed Grass Prairie Inventory project has conducted surveys of prairie throughout southwestern Manitoba, and Buffalograss has never been observed outside of the range reported here.

In Manitoba, Buffalograss appears to be restricted to a specific soil type characterized by shallow clay to clay loam alluvial deposits over marine shale bedrock. This soil type has a severely limited capability for crop 
production because of undesirable soil structure, low permeability, and the presence of soluble salts; ${ }^{2}$ therefore, threats from cultivation are likely minimal. In other parts of its range, Buffalograss tolerates a wide range of soil conditions, but prefers clay or clay loam soils.?

\section{Potential threats to buffalograss populations}

Buffalograss is threatened by the encroachment of non-native species like Kentucky Bluegrass (Poa pratensis) and Leafy Spurge (Euphorbia esula). Dams can flood the habitat of Buffalograss; one such dam, Dam 357 on the Souris River, can be seen just south of the Canadian border in North Dakota. Buffalograss may require moderate to heavy grazing to remove competing grasses and forbs, ${ }^{4}$ but grazing must be managed carefully to minimize the negative effects of heavy grazing on mixed grass prairie. Overgrazing increases the amount of bare ground and allows species like Curlycup Gumweed and Prairie Sagewort which are not palatable to cattle, to increase in abundance. ${ }^{5}$ Newly exposed bare ground also provides a fertile seedbed for invasive species, including non-native species like Leafy Spurge which may become established and spread to other areas. Avoiding early and late season grazing could help improve the quality of native prairie. ${ }^{5}$

\section{Conclusions}

There is a need for basic inventories to catalog remaining natural areas, as these provide habitat for rare species. This information is important for the preparation of recovery plans, and to make informed decisions on the status of this species. Continuing sound stewardship of remnant prairie in the Souris River Valley is important to maintain critical habitat for Buffalograss and other rare species.

\section{Acknowledgements}

This project would not have been possible without cooperation among many agencies and individuals. The Habitat Stewardship Program, Manitoba Special Conservation Fund, and the Critical Wildlife Habitat Program (a program delivered cooperatively by the Wildlife and Ecosystem Protection Branch and MHHC) provided funding for this survey. Manitoba Conservation staff provided support, especially Jim Duncan, Jason Greenall, Peggy Westhorpe, and Ken De Smet. Kyle Cannon provided field assistance as part of the Rural Green Team. A special thanks to the many landowners in the Souris and Blind River Valleys who provided access to their lands and whose stewardship has allowed Buffalograss and other rare species to persist in the Souris River Valley. The authors thank Prairie Mountain Roots of Arcola, SK for providing the seeds shown in Figure 2, and Anna Leighton for providing the photograph.

1. BOIVIN, B. 1981. Flora of the Prairie Provinces. A handbook to the flora of the provinces of Manitoba, Saskatchewan and Alberta. Part V. Gramineae. Provancheria 12: 1-108.

2. EILERS, R.G., L.A. HOPKINS, R.E. SMITH. 1978. Soils of the BoissevainMelita Area Soils Report No. 20. Manitoba Department of Agriculture. Winnipeg, MB. 204 pp.

3. GLEASON, H.A., AND A. CRONQUIST. 1991. Manual of the Vascular Plants of Northeastern United States and Adjacent Canada Second Edition. The New York Botanical Garden, New York. 910 pp.

4. HARMS, V.L. 1997. Status Report on Buffalograss (Buchloë dactyloides) in Canada. Committee on the Status of Endangered Wildlife in Canada, Ottawa, ON. 38 pp.

5. MANSELL, T., AND J. MOORE. 1999. Mixed-grass Prairie Inventory for 
Manitoba 1992-1998: Interim Status Report. Critical Wildlife Habitat Program and Manitoba Natural Resources Wildlife Branch. Winnipeg, Manitoba. 135 pp.

6. NATURESERVE EXPLORER: AN ONLINE ENCYCLOPEDIA OF LIFE [WEB APPLICATION]. 2001. Version 1.6.
Arlington, Virginia, USA: NatureServe. http:/ /www.natureserve.org/explorer/ (accessed March 31, 2003).

7. US DEPARTMENT OF AGRICULTURE. 2002. Natural Resources Conservation Service Plant Fact Sheet Buffalograss. USDA NRCS Plant Materials Program, Washington D.C. 2 pp.

Figure 4. Buffalograss habitat in the Souris River Valley.

"This morning, when I had been lying for a long time on a rock near the sea watching some hooded crows that were dropping shellfish on the rocks to break them, I saw one bird that had a large white object which it was dropping continually without any result. I got some stones and tried to drive it off when the thing had fallen, but several times the bird was too quick for me and made off with it before I could get down to him. At last, however, I dropped a stone almost on top of him and he flew away. I clambered down hastily, and found to my amazement a worn golf-ball. No doubt it had been brought out in some way or other from the links in County Clare, which are not far off, and the bird had been trying half the morning to break it."

- J.M. Synge. 1901. The Aran Islands, part IV. 